\title{
TECHNOLOGICAL, TECHNICAL AND QUALITY ASSESSMENT OF MAIZE SILAGE MAKING AND UNLOADING FROM TRENCH
}

\begin{abstract}
Algirdas JASINSKAS, Institute of Agricultural Engineering and Safety, Faculty of Agricultural Engineering, Vytautas Magnus University, K. Donelaičio g. 58, LT-44248 Kaunas, Lithuania algirdas.jasinskas@ vdu.lt (corresponding author)

Gytis PAŠVENSKAS, Institute of Agricultural Engineering and Safety, Faculty of Agricultural Engineering, Vytautas Magnus University, K. Donelaičio g. 58, LT-44248 Kaunas, Lithuania gytis.pasvenskas@ gmail.com

Mečys PALŠAUSKAS, Institute of Agricultural Engineering and Safety, Faculty of Agricultural Engineering, Vytautas Magnus University, K. Donelaičio g. 58, LT-44248 Kaunas, Lithuania mecys.palsauskas@ @du.lt

Jiří SOUČEK, Research Institute of Agricultural Engineering, p.r.i., Drnovská 507, Praha 6-Ruzyně 161 01, Praha 614, Chech Republic; jiri.soucek@vuzt.cz

Silage for animal feeding can be made from different plants. One of the most important feed crops from which silage is made is maize. Special choppers can be used for cutting and chopping these coarse-stem plants. The most widespread silage preparation is done in trenches, where good quality silage can last for several years, making it one of the best feeds in winter. Incorrect picking and unloading of silage from trenches may result in secondary fermentation and may cause forage losses. Various types of equipment are used for silo unloading from storage. This-work researches maize plants, the quality of maize silage and the process of silage making and unloading. The research was carried out in the laboratories of Agriculture Academy of Vytautas Magnus University and in a farmer's farm. Tests have been performed with three different silo unloaders and a mobile feed mixer. The established average corn plant yield in 2018 was $31.8 \mathrm{t} \mathrm{ha}^{-1}$; for silage making, the plants were chopped with the drum chopper. After evaluation of the fractional composition of chopped mass, the chopped maize slices were found to meet the silage production requirements, as even $82.6 \%$ of the chopped particles were 3.15-16 mm long. Maize slice moisture was also found to be suitable for silage $-66.12 \pm 7.3 \%$. The density of prepared silage was high enough and reached $699.89 \pm 19.04 \mathrm{~kg} \mathrm{~m}^{-3}$ or $230.55 \pm 6.27 \mathrm{~kg} \mathrm{~m}^{-3} \mathrm{DM}$ (dry matter). Silage unloaders test results showed that one sample of silage could be unloaded in 31-43 s. The bucket type device could take the maximum weight sample $-567.8 \pm 77.0 \mathrm{~kg}$, but the maximum density of the silage sample $\left(30.41 \pm 1.95 \mathrm{~kg} \mathrm{~m}^{-3}\right)$ could be taken by a block-cutting unit. Also, this unloader left the smallest unevenness on the feed surface. Distribution of feed in the farm for the animal was fairly even and this indicated that the silage-unloading device had no significant impact on the quality of feed distribution.
\end{abstract}

Keywords: animal feeding, maize, silage making, technologies, unloading, distribution.

\section{INTRODUCTION}

Silage is a fermented green juicy feed that can be made from a variety of plants: corn, cultural meadows and pastures, clover, timothy, rape, vetch, oats, etc. It is preserved with organic acids, the most important of which is lactic acid. Lactic acid protects the feed from damage. Almost all the plant's properties are preserved in this feed. Good quality silage can last for several years, making it one of the best feeds in winter.

The chemical composition of silage and its feed value are determined by different factors, such as: plants from which it has been produced, vegetation stage of the plant during cutting, drying time, mass fermentation and so on. The success of fermentation is determined by the main indicators of silage quality: crude protein, crude fiber, $\mathrm{pH}$, milk and butter acid, sugar, ammoniac nitrogen, etc. (Baranauskas et al., 2009).

One of the most important feed crops from which silage is made is maize. For preparation, maze is shredded with special shredders (Gudaitis, 2016). Corn ferments well and quickly, so no additional additives are needed for silos. To make silage properly, it is important to fill the silo tank (trench, plastic trowel) in a short period of time, pressurise it well, cover tightly and press (Sirvydis, 2001). In preparation of maize silage, 1 ha of feed energy is obtained, which is not obtained from any other feed plant intended for feeding to cattle (Samalionienè, 2017).

The quality of farmed feed is a key indicator of farm profitability, especially when silage accounts for more than $50 \%$ of the daily ration of cows. Regrettably, frequent losses are common in farms due to various silage production errors. Therefore, it is very important to use proper technique to monitor and control all stages of silage preparation and its unloading from storage (Zigmantienè, 2017; Bacenetti, Fusib, 2015).

Incorrect picking of feed from storage may result in secondary fermentation. Depending on the conditions of preparation and storage of the feed used on each farm, individual decisions must be taken to unload various silage fodder. Different types of equipment can be used to do this (Kaiser et al., 2003).

Aim of research. To perform a technological-technical evaluation of silage preparation and extraction from a trench and to determine the quality of the prepared silage unloading and distribution on the farm.

Copyright (C) 2019 The Authors. Published by Vytautas Magnus University. This is an open-access article distributed under the terms of the Creative Commons Attribution License (CC BY 4.0), which permits unrestricted use, distribution, and reproduction in any medium, provided the original author and source are credited. 


\section{MATERIALS AND METHODS}

Experimental research was conducted in 2018-2019 in the mixed farm of Gediminas Pašvenskas. There were 125 cattle kept on farms for which hay and corn silage was produced. Maize was cut and chipped with a John Deere 8700 self-propelled crusher with 375 Plus 10 rows.

The plants that were used for research, had grown in the same field, under the same conditions. The biometric characteristics of cut and crushed maize were determined: dimensions, weight, moisture, yield and fractional composition of the cut. Some indicators were measured directly, while others were calculated.

The moisture content of corn samples was determined in the chemical laboratory according to the standard methodology (Jasinskas, Zvicevičius, 2008). The methodology (Jasinskas, Zvicevičius, 2008) used in the EU countries was used to evaluate the quality (fractional composition) of corn. The fractional composition of the cut was determined using a set of sieves with a diameter of $400 \mathrm{~mm}$, where the sieves with square holes were placed on top of each other (in the order from the top sieve): $63 \mathrm{~mm}, 45 \mathrm{~mm}, 16 \mathrm{~mm}, 8 \mathrm{~mm}, 3.15 \mathrm{~mm}$ and $1 \mathrm{~mm}$ in length (give dimensions of the square edge). $0.5 \mathrm{~kg}$ of corn slice sample was sieved with a special Haver EML Digital plus sieve shaker, where the sieve set vibrated in the horizontal plane for 1 minute. The remaining mass on the sieves was weighted and the percentage (\%) of the sample for each fraction as well as the mean of the measurements with the confidence average square error were calculated (Tučkutė et al., 2018).

The grain crushing system of the forage harvester was evaluated by corn grain injury. Crushed corn mass was taken from 10 grains, it was visually inspected and divided into three groups: crushed, injured and intact. Each test was repeated 20 times. The average of each grain group with the confidence in the average square error was calculated.

After preparing the silage and opening the trench, density and humidity were determined. To calculate the density of the prepared maize silage, 5 samples were taken from the sides and from the middle of the trench. The samples were taken at a height of 1.0-1.1 m from the bottom of the trench. Selected size of rectangular silo was cut with a special knife or saw. The volume of the rectangle was calculated. The vessel with a sample was weighted. The average density of the silage and humidity with a confidence interval of their data change were calculated.

Comparative tests of silo unloading were carried out using Case IH Maxxum 110 wheeled tractor with Quicke Q56 front loader. Three different types of silo unloading equipment were connected to this tractor: manure-silage fork made of silage, silo cutter Quicke SiloCut 150 SE manufactured by UAB Laumetris and BVL van Lengerich $110 E$ silo unloader.

During the tests, the silage pickup chronometer was used during accessing to the silo, opening or closing of the unit, silage removal or cutting, accessing the dispenser or cradle and tipping. Time was measured with a stopwatch with an accuracy of $1.0 \mathrm{~s}$. The silo unloading cyclogram consisted of 5 tests.

The characteristics of the sample of maize silage taken by the device were investigated. We measured the dimensions of the silage sample. Measurements were made by a tape ( $1 \mathrm{~mm}$ accuracy). The volume of the sample was calculated. The weight of the silage was poured into a $14 \mathrm{~m}^{3}$ hopper of the Kverneland Siloking Duo 14 mobile feed mixer, weighing $1 \mathrm{~kg}$ with electronic weighing scales. The density of the maize silage sample taken by the device was calculated.

Silage pick-up units leave different monolith unevenness in the remaining feed in the trench. Some of them are very disgusting, ridding and shedding their feed. Then the feed quickly fades, its quality deteriorates. To avoid that, the silage cut must be smooth, unexploded, and the mass structure must not broken (Sirvydis, 2004).

During tests, we measured the unevenness on the surface of the remaining feed in the trench. It was measured by a measuring tape (accuracy of readings $1 \mathrm{~mm}$ ) from a flat, non-tearing surface. The mean roughness of each sample with its confidence interval was calculated.

The silage distribution uniformity tests were carried out using the aforementioned feed divider. When the feed from the trench was taken from the device, the dispenser hopper was loaded with a mass of 1600-1700 kg and distributed to the cattle on the farm. The weight of the distributed silage from 5 different feed path locations (with $5 \mathrm{~m}$ distance) was weighed out. Each test was repeated 5 times. The meaning of the samples with the confidence of the average square error was calculated.

\section{RESULTS AND DISCUSSION}

Biometric indicators were determined for the maize plants prior to crushing. The corn cob was measured in the laboratory: weight $264 \pm 41.64 \mathrm{~g}$, length $188 \pm 11.65 \mathrm{~mm}$ and width $47.28 \pm 5.87 \mathrm{~mm}$. Biometric indicators of maize stems were also identified. The total mast weight was $189.2 \pm 70.61 \mathrm{~g}$ and the length $2127.8 \pm 314.59 \mathrm{~mm}$, diameter $0.1 \mathrm{~m}$ from the ground surface $21.7 \pm 3.43 \mathrm{~mm}$ and stem density $0.56 \pm 0.11 \mathrm{~kg} \mathrm{~m}^{3}$. The moisture content of the chopped maize was $66.12 \pm 7.3 \%$, and the dry matter average was $33.88 \%$. The results showed that maize slice moisture was suitable for silage (it is best to silage with a moisture content of 65-70\%) (Bartkevičiūtè, 2007).

The theoretical yield of maize $\left(\mathrm{t} \mathrm{ha}^{-1}\right)$ was determined just before mass chopping. The estimated average weight loss was $41.33 \pm 7.61 \mathrm{t} \mathrm{ha}^{-1}$ without the loss of cutting height and uncut plants. The average height of maize cutting was $27.92 \pm 1.85 \mathrm{~cm}$. The practical yield of maize green mass was calculated to be $31.8 \mathrm{t} \mathrm{ha}^{-1}$, whereas calculated dry matter yield was $10.77 \mathrm{t} \mathrm{ha}^{-1}$.

The maize slice fraction studies showed that $(55.33 \pm 8.19 \%)$ maize slice mostly contained particles with a length of $8-16 \mathrm{~mm}$ and at least $(1.73 \pm 0.19 \%) 0-1 \mathrm{~mm}$ in size. Chopped maize slices met silage production requirements, as 
even $82.6 \%$ of the finely divided particles had a length of $3.15-16 \mathrm{~mm}$. According to the requirements, the theoretical chaff length should be 5-8 mm (Špokas, 2010).

The grain crushing system of the forage harvester was also evaluated, having in mind that all corn grains must be crushed or damaged. A total of 200 grains were found to be $71.5 \pm 5.53 \%$ crushed, $27.5 \pm 5.23 \%$ injured and $1.44 \pm 1.0 \%$ intact.

The chronometric procedure of separate technological operations of maize silage technology was performed. Determined duration of the technological operations was as follows:

- Maize chopping - 3 hours;

- Ensiled mass levelling and pressure - 2.5 hours;

- Ensiled mass pressure after plant chopping - 2 hours;

- Trench covering - 2 hours;

- The whole production cycle -9.5 hours.

The maize trench was filled with 219.4 tonnes of green mass and covered on the same day. The density of prepared maize silage was $699.89 \pm 19.04 \mathrm{~kg} \mathrm{~m}^{-3}$ or $230.55 \pm 6.27 \mathrm{~kg} \mathrm{~m}^{-3} \mathrm{DM}$ (dry matter) and met the recommended compression density of at least $200 \mathrm{~kg} \mathrm{~m}^{-3} \mathrm{DM}$. In the laboratory, maize silage humidity with a confidence interval of $67.07 \pm 1.07 \%$ was tested and calculated.

The chronometric checklist of silage unloading operations is shown in Table 1.

Table 1. The chronometric procedures of silage unloading operations

\begin{tabular}{|c|c|c|c|c|c|c|}
\hline \multicolumn{7}{|c|}{ Silage unloading operations and their duration, $\mathrm{s}$} \\
\hline Equipment & 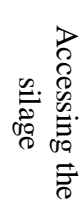 & 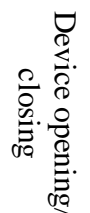 & 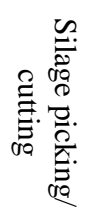 & 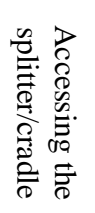 & 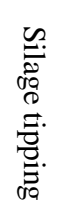 & 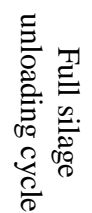 \\
\hline Forks with pressing & $8-12$ & $3-5$ & $7-9$ & $12-15$ & $1-2$ & $31-43$ \\
\hline Bucket type & $8-12$ & $11-13$ & $14-21$ & $13-16$ & $1-2$ & $47-64$ \\
\hline Block-cutting & $9-13$ & - & $58-64$ & $10-13$ & $2-3$ & $79-93$ \\
\hline
\end{tabular}

The entire silage unloading cycle lasted for the shortest time when using the forks with pressing $-31-43 \mathrm{~s}$, and the longest - when using the block-cutting equipment - 79-93 s. The duration of accessing the silage depends on the location of the silage in the trench site. The larger and heavier the silage sample is taken, the longer it takes for the machine to cut back or cut it.

The characteristics of the maze silage samples taken with the equipment were investigated (Table 2).

Table 2. The characteristics of the maize silage samples taken with silage unloading equipment

\begin{tabular}{|c|c|c|c|}
\hline Equipment & Mass, $\mathrm{kg}$ & Volume, $\mathrm{m}^{3}$ & Density, $\mathrm{kg} \mathrm{m}^{-3}$ \\
\hline Forks with pressing & $556.0 \pm 28.9$ & $0.80 \pm 0.04$ & $\begin{array}{c}696.78 \pm 2.69 \\
229.52 \pm 0.89 D M\end{array}$ \\
\hline Bucket-type & $567.8 \pm 77.0$ & $0.88 \pm 0.08$ & $\begin{array}{c}644.73 \pm 25.65 \\
212.38 \pm 8.45 D M\end{array}$ \\
\hline Block-cutting & $521.8 \pm 26.2$ & $0.75 \pm 0.03$ & $\begin{array}{c}699.49 \pm 5.93 \\
230.41 \pm 1.95 D M\end{array}$ \\
\hline
\end{tabular}

When using a bucket-type equipment, a maximum mass sample of $567.8 \pm 77.04 \mathrm{~kg}$ can be taken from the trench because of its maximum dimensions. However, the highest density of maize silage sample $\left(230.41 \pm 1.95 \mathrm{DM} \mathrm{kg} \mathrm{m}^{-3}\right)$ is obtained using the block-cutting unit, because the block is cut and does not deform, its density remains similar to that of the silage in the trench.

When testing the silage unloaders, unevenness was found on the surface of the remaining forage in the trench from the flat, unshielded surface and the forage distribution on the farm feeder (Table 3).

Table 3. Unevenness on the surface of the forage and the distribution of silage on the farm feeder using different forage unloading equipment.

\begin{tabular}{|c|c|c|}
\hline Equipment & On the forage surface, $\mathrm{mm}$ & On the farm feeder, $\mathrm{kg}$ \\
\hline Forks with pressing & $4.31 \pm 0.89$ & $32.72 \pm 0.48$ \\
\hline Bucket-type & $3.17 \pm 0.75$ & $31.92 \pm 1.05$ \\
\hline Block-cutting & $1.45 \pm 0.14$ & - \\
\hline
\end{tabular}

The maximum unevenness on the forage surface after silage unloading was $4.31 \pm 0.89 \mathrm{~mm}$ left by the use of the forks with pressing, and the smallest $-1.45 \pm 0.14 \mathrm{~mm}$ by the use of block-cutting silage unloader. Forage distribution 
on the farm feeder was fairly even and ranged from $31.92 \pm 1.05$ to $32.72 \pm 0.48 \mathrm{~kg}$ in individual cattle feeding areas. This indicated that the silage-unloading device had no significant impact on the quality of feed distribution.

There was no possibility of directly cutting the silage sample cut into the mobile feed dispenser with a blockcutting equipment, so these tests were not performed.

\section{CONCLUSIONS}

1. The average yield of harvested maize plant mass was determined, it reached $31.8 \mathrm{t} \mathrm{ha}^{-1} \mathrm{of}_{\text {green mass. The moisture }}$ content of the maize crop and chopped mass was suitable for silage and was $66.12 \pm 7.3 \%$ (maize mass is best for silage at the humidity of $65-70 \%)$.

2. Chopped maize slices met silage production requirements, as even $82.6 \%$ of the crushed particles had a length of 3.15-16 mm. According to the requirements, the theoretical length of chaff must be 5-8 mm.

3. The production of maize silage lasted for 9.5 hours. The density of the prepared silage was $699.89 \pm 19.04 \mathrm{~kg} \mathrm{~m}^{-3}$ or $230.55 \pm 6.27 \mathrm{~kg} \mathrm{~m}^{-3} \mathrm{DM}$ (dry mass) and met the recommended compression density of at least $200 \mathrm{~kg} \mathrm{~m}^{-3} \mathrm{DM}$.

4. Testing with silage unloading equipment showed that it was likely that silage would be unloaded using forks with pressing - 31-43 s. The bucket-type device could take the maximum weight sample $-567.8 \pm 77.04 \mathrm{~kg}$, but the maximum density of silage sample was $230.41 \pm 1.95 \mathrm{~kg} \mathrm{~m}^{-3} \mathrm{DM}$ when using a block-cutting equipment. Also, this unloader left the smallest unevenness on the fodder surface $-1.45 \pm 0.14 \mathrm{~mm}$.

5. Distribution of feed on the farm feeder was fairly even and ranged from $31.92 \pm 1.05$ to $32.72 \pm 0.48 \mathrm{~kg}$ in the feeding areas of individual cattle. This indicated that the silage-unloading device had no significant impact on the quality of feed distribution.

\section{REFERENCES}

1. Bacenetti J., Fusib A. 2015. The environmental burdens of maize silage production: Influence of different ensiling techniques. Animal Feed Science and Technology 204, 88-98. https://doi.org/10.1016/j.anifeedsci.2015.03.005

2. Baranauskas S., Juknevičius S., Stankevičiūtè J. 2009. Feed and cattle feeding: Educational Book. Akademija, Kaunas r.: Publishing Center of Aleksandras Stulginskis University. Available at http://asu.lt/wpcontent/uploads/2015/02/mokomoji_knyga.pdf (accessed on 02/02/2019).

3. Bartkevičiūtè Z. 2007. Corn silage quality factors. Available at http://www.manoukis.lt/mano-ukis-zurnalas/2007/08/kukuruzusiloso-kokybe-lemiantys-veiksniai (accessed on 03/02/2019)

4. Gudaitis A. 2016. Cultivation of maize for fodder - fully beneficial. Available at http://www.agroakademija.lt/Straipsniai/StraipPerziura? StraipsnisID=1223\&TemaID=2 (accessed on 02/02/2019).

5. Jasinskas A., Zvicevičius E. 2008. Preparation of coarse-stem biomass for energy production: Methodological advice for laboratory work. Akademija, Kaunas r., 48 p.

6. Kaiser A.G., Piltz J.W., Burns H.M., Griffiths N.W. 2003. TopFodder: Successful silage. NSW Agriculture and Dairy Research and Development Corporation. Australia, 420 p.

7. Samalionienè R. 2017. Avoid mistakes by producing corn silage. Available at http://www.agroakademija.lt/Straipsniai/StraipPerziura? StraipsnisID=8861\&TemaID=2 (accessed on 05/02/2019).

8. Sirvydis J. 2001. Production of herbaceous forage: A Monograph. Raudondvaris, Lithuanian Institute of Agricultural Engineering, $186 \mathrm{p}$.

9. Sirvydis, J. 2004. Silage producer Manual. Raudondvaris, 89 p.

10. Špokas, L. 2010. Maize silage production technology. Available at http://www.manoukis.lt/mano-ukiszurnalas/2010/10/kukuruzu-siloso-gamybos-technologija/ (accessed on 03/02/2019).

11. Tučkute L., Streikus D., Jasinskas A., Pedišius N., Vonžodas T. 2018. Investigation of bulrush preparation and usage for burning and determination of harmful substances emissions. Proceedings of the 24th International Scientific-Practice Conference „Human and Nature Safety 2018“, 42-46, Aleksandras Stulginskis University.

12. Zigmantienè I. 2017. Peculiarities of silage. Available at http://www.agroakademija.lt/Straipsniai/StraipPerziura? StraipsnisID=10850\&TemaID=2 (accessed on 05/02/2019). 